\title{
APLIKASI TECHNOLOGY ACCEPTANCE MODEL PADA MINAT NASABAH UNTUK MENGGUNAKAN INTERNET BANKING
}

\author{
Andrew Gunawan \\ Sekolah Tinggi Ilmu Ekonomi Musi \\ glakuraku@yahoo.co.id
}

\begin{abstract}
Abstrak: Tujuan utama dari penelitian ini adalah untuk menganalisis faktor-faktor yang mempengaruhi minat seorang nasabah untuk mau menggunakan Sistem Informasi Akuntansi Perbankan berupa Internet Banking dengan menggunakan Technology Acceptance Model (TAM). Selain itu, peneliti juga menambahkan konstruk laten berupa persepsi keamanan kedalam TAM. Objek dalam penelitian ini adalah nasabah Bank Central Asia yang ada di kota Palembang dengan pertimbangan bahwa Bank Central Asia merupakan Bank pelopor Internet Banking di Indonesia sejak tahun 2000 dan mempunyai volume transaksi perbankan yang tertinggi pada akhir tahun 2012 dibandingkan dengan Bank lainnya. Sebanyak 194 sampel diambil dan dianalisis dengan menggunakan Structual Equation Model (SEM). Hasilnya menunjukkan bahwa persepsi kegunaan, persepsi kemudahan penggunaan, persepsi keamanan, dan sikap berhubungan positif secara signifikan dengan minat nasabah Bank Central Asia di Kota Palembang untuk menggunakan Internet Banking. Selain itu juga ditemukan fenomena bahwa ternyata persepsi kegunaan tidak berpengaruh secara langsung terhadap minat, melainkan berpengaruh secara tidak langsung melalui sikap. Fenomena ini sebenarnya disebabkan oleh faktor demografis berupa perbedaan tempat dan waktu dilakukannya penelitian menjadi penyebab utama terjadinya perbedaan hasil penelitian ini dengan dasar teori yang ada dan penelitian terdahulu.
\end{abstract}

Kata Kunci: Sistem Informasi Akuntansi, E-Banking, TAM, SEM

Abstract: The main objective of this study was to analyze the factor which affected the customers' interest in using the Accounting Information System such as Internet Banking using Technology Acceptence Model (TAM). Moreover, I also added the latent constructs of security perception in TAM. The objects of this study were the customers of Bank Central Asia in Palembang considering the fact that Bank Central Asia was the pioneer Bank which has used the Internet Banking since 2000 in Indonesia and it has had the highest volume of banking transactions by the end of 2012 comparison with the other bank. Total of 194 respondent were sampled and analyzed using the structual equation model (SEM). It was found that the perceived usefulness, ease of use, security perceptions, and attitudes affected significantly and positively the customers interests on using the Internet Banking at Bank Central Asia. It was also found that the perceived usefulness did not have direct affect on the customer's interest, but it had indirect effect on customers interest through attitudes. This occured because there were differences in where and when this study had been conducted which had led to the different results of study from the available theory and previous studies.

Keywords : Accounting Information System, E-Banking, TAM, SEM 


\section{JURNAL NOMINAL / VOLUME III NOMOR 2 / TAHUN 2014}

\section{PENDAHULUAN}

Pada akhir tahun 2012, tercatat ada 2.405.518.376 pengguna internet di seluruh dunia. Dari keseluruhan jumlah tersebut, 1.076.681.059 pengguna diantaranya berasal dari Asia. Indonesia sendiri menempati posisi ke-4 dengan jumlah pengguna internet sekitar 55.214.702 jiwa di kawasan Asia setelah Jepang, India, dan China (Internet World Stats, 2012). Melihat potensi ini, banyak bank di Indonesia yang semakin gencar untuk mempromosikan layanan perbankannya secara online, yaitu dengan menggunakan media internet.

Secara umum, Internet Banking merupakan bentuk inovasi di bidang teknologi berbasis pada ilmu akuntansi (Karjualto, 2002). Dalam ruang lingkup ilmu akuntansi, Internet Banking diklasifikasikan sebagai sistem pemrosesan transaksi yang terotomatisasi atau yang sering diidentifikasi sebagai bagian dari sistem informasi akuntansi (SIA). Sistem pemrosesan transaksi berfungsi mengkonversikan berbagai kegiatan ekonomi ke dalam transaksi keuangan, mencatatnya dan melaporkannya kepada pengguna akhir (end user) baik kepada pihak internal maupun eksternal. Sistem ini berperan penting dalam mempermudah dan memperlancar proses akuntansi. Hal ini membuat keberadaan Internet Banking diharapkan dapat memberikan manfaat bagi semua pihak yang menerapkannya.
Sejarah penerapan Internet Banking di Indonesia sendiri telah dimulai sejak tahun 1998. Dimana Bank Internasional Indonesia (BII) menjadi bank pertama di Indonesia yang menerapkan sistem informasi Internet Banking. Kemudian penerapan Internet Banking tersebut juga dilakukan oleh Bank Central Asia dan Bank Niaga pada tahun 2000, Bank Bukopin pada tahun 2001, Bank Mandiri pada tahun 2003, Bank Permata pada tahun 2005, Bank Negara Indonesia pada tahun 2007, Bank Danamon pada tahun 2008, Bank Rakyat Indonesia pada tahun 2009, dan yang terakhir Bank Mega pada tahun 2010. Diantara bank-bank tersebut, Bank Central Asia merupakan bank yang dianggap paling berhasil dalam penerapan Internet Banking di Indonesia.

Ada beberapa alasan yang mendasari ketertarikan bank-bank untuk menerapkan sistem informasi Internet Banking (Karjaluato, 2002). Yang pertama adalah pihak bank menyadari bahwa pertumbuhan pengguna internet di Indonesia berlangsung sangat pesat. Hal ini menyebabkan pihak bank mengharapkan pertumbuhan pengguna Internet Banking juga akan tumbuh dengan pesat seiring dengan pertumbuhan pengguna internet. Alasan yang terakhir adalah pihak bank ingin mengefisiensikan beban anggarannya. Artinya, pihak bank merasa bahwa penerapan sistem informasi akuntansi berupa Internet Banking relatif jauh lebih murah dibandingkan dengan harus 


\section{JURNAL NOMINAL / VOLUME III NOMOR 2 / TAHUN 2014}

membangun fasilitas-fasilitas perbankan secara fisik seperti Anjungan Tunai Mandiri (ATM) dan kantor cabang guna memenuhi kebutuhan transaksi nasabah.

Walaupun demikian, fasilitas Internet Banking sendiri ternyata belum terlalu diminati oleh para nasabah bank di Indonesia. Hal ini terbukti dengan jumlah nasabah pemakai Internet Banking yang baru mencapai angka $27 \%$ dari keseluruhan nasabah bank yang menerapkan Internet Banking di Indonesia (Kompas, 2012). Contohnya adalah Bank Central Asia (BCA), dimana dari 9,4 juta nasabah Bank Central Asia pada tahun 2012, hanya sekitar 1,4 juta nasabah yang terdaftar dalam layanan Internet Banking. Sementara itu nasabah yang benar-benar aktif menggunakannya hanya sekitar 942.000 nasabah. Apabila data tersebut dikalkulasikan maka hanya terdapat $14,89 \%$ saja pengguna fasilitas Internet Banking BCA di Indonesia (Info Bank News, 2012).

Berdasarkan pada data tersebut maka dapat disimpulkan bahwa telah terjadi kegagalan sistem apabila dilihat dari segi penggunaan sistem (system use) berdasarkan keenam dimensi kesuksesan yang dikemukakan oleh DeLone dan McLean (1992). Untuk mengetahui faktor-faktor yang mempengaruhi minat nasabah untuk menggunakan sistem informasi akuntansi berupa Internet Banking, peneliti akan menggunakan model Technology Acceptance Model (TAM).

\section{Sistem Informasi Akuntansi (SIA)}

Sistem informasi akuntansi didefinisikan sebagai sebuah sistem informasi yang dapat merubah data transaksi bisnis menjadi informasi keuangan yang berguna bagi para penggunanya baik pihak eksternal maupun internal (James, 2009). Sistem informasi akuntansi sendiri dibagi kembali menjadi 3 subsistem, yaitu:
a. Sistem pemrosesan transaksi
b. Sistem buku besar / pelaporan keuangan
c. Sistem pelaporan manajemen

Sistem pemrosesan transaksi berfungsi untuk mengkonversikan kegiatan ekonomi ke dalam transaksi keuangan, mencatat berbagai transaksi keuangan ke dalam transaksi keuangan, dan mendistribusikan informasi keuangan yang penting untuk pihak internal maupun eksternal. Sistem buku besar/ pelaporan keuangan berfungsi untuk mengukur dan melaporkan kondisi sumber daya keuangan serta berbagai perubahan atas sumber daya tersebut. Terakhir, sistem pelaporan manajemen berfungsi untuk memberikan informasi keuangan internal yang dibutuhkan untuk mengelola bisnis.

Pada dasarnya ketiga subsistem ini merupakan satu kesatuan dan dalam 


\section{JURNAL NOMINAL / VOLUME III NOMOR 2 / TAHUN 2014}

perkembangannya sekarang telah dikombinasikan dengan kemajuan teknologi terutama yang berbasis komputerisasi dan secara real-time maupun online. Salah satu contoh perpaduan teknologi dalam sistem informasi akuntansi adalah E-Banking yang banyak digunakan untuk kebutuhan internal maupun eksternal perbankan. Menurut Bur (1996) dalam Wadie Nasri et al (2011) Secara sederhana E-Banking dapat didefinisikan sebagai fasilitas penyediaan informasi atau layanan dari bank kepada nasabahnya melalui berbagai media seperti komputer, televisi, telepon, ataupun telepon genggam. Lebih jauh lagi, perkembangan EBanking pada saat ini telah terfokus pada media internet atau yang paling sering kita sebut dengan Internet Banking yang dikategorikan sebagai sebuah sistem informasi akuntansi perbankan.

\section{Technology Acceptance Model (TAM)}

Model Technology Acceptance

Model (TAM) diadopsi dan dikembangkan dari model The Theory of Reasoned Action (TRA), yaitu teori tindakan yang beralasan yang dikembangkan oleh Fishbein dan Azjen (1980), dengan satu premis bahwa reaksi dan persepsi seseorang terhadap sesuatu hal, akan menentukan sikap dan perilaku orang tersebut. Technology Acceptance Model (TAM) sendiri dikembangkan untuk menjelaskan perilaku penggunaan teknologi.
Model TAM yang dikembangkan oleh Davis F.D (1989) dan merupakan salah satu model yang paling banyak digunakan dalam penelitian teknologi informasi, perilaku akuntansi, dan psikologi (Adam.et.al, 1992; Chin dan Todd, 1995; Igbaria.et.al, 1997; Mhd.Jantan.et.al, 2001; dalam Jogiyanto, 2007). Sampai saat ini TAM merupakan model yang paling banyak digunakan dalam memprediksi penerimaan teknologi informasi (Gefen, 2002) dan telah terbukti menjadi model teoritis yang sangat berguna dalam membantu memahami dan menjelaskan perilaku pemakai dalam implementasi sistem informasi (Legris.et.al, 2003).

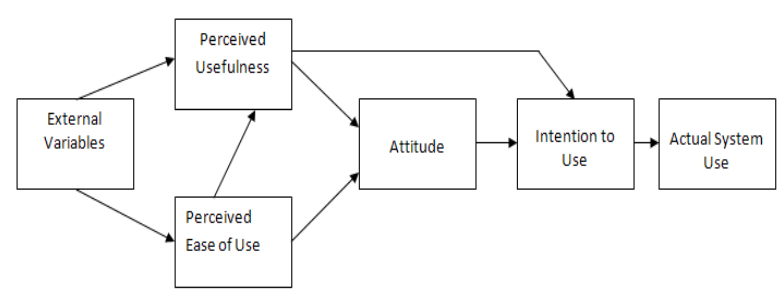

Gambar 2.1. Technology Acceptance Model Sumber : Davis F.D. (1989)

\section{Penelitian Terdahulu}

Alsajjan dan Dennis (2006) meneliti mengenai pengaruh kepercayaan terhadap penerimaan Internet Banking dengan menggunakan perpaduan teori Theory Reasoned Action dan Technology Acceptance Model (TAM). Hasil penelitiannya menunjukkan bahwa persepsi kegunaan, persepsi kemudahan penggunaan, 


\section{JURNAL NOMINAL / VOLUME III NOMOR 2 / TAHUN 2014}

dan kepercayaan (trust) berpengaruh positif dan signifikan terhadap sikap. Kemudian ditemukan juga bahwa sikap berpengaruh positif dan siginfikan terhadap minat untuk menggunakan Internet Banking di London.

Kusuma dan Susilowati (2007) meneliti mengenai determinan pengadopsian layanan Internet Banking melalui perspektif konsumen perbankan (nasabah) dengan menggunakan model TAM yang telah dimodifikasi. Hasil penelitiannya menunjukkan persepsi manfaat tidak berhubungan signifikan dengan sikap dan persepsi kemudahan penggunaan berhubungan signifikan dengan sikap. Selain itu juga didapati kesesuaian tugas dan jasa aliansi berhubungan signifikan dengan persepsi manfaat, personalisasi berhubungan tidak signifikan terhadap persepsi manfaat. Kemudian, jasa aliansi, kesesuaian tugas dan kemampuan akses berpengaruh signifikan dengan persepsi kemudahan penggunaan.

Lallmahamood (2007) meneliti mengenai faktor-faktor yang mempengaruhi adopsi nasabah bank terhadap Internet Banking di Malaysia dengan menggunakan model Technology Acceptance Model (TAM). Selain menggunakan model TAM, penelitian ini juga memasukkan variabel tambahan seperti persepsi keamanan dan privasi untuk ditambahkan dalam model penelitiannya. Hasil penelitiannya menunjukkan bahwa selain persepsi kegunaan dan persepsi kemudahan penggunaan yang terdapat di dalam model TAM, persepsi keamanan dan privasi juga merupakan variabel yang berpengaruh signifikan terhadap minat untuk menggunakan Internet Banking di Malaysia.

Amin (2007) meneliti mengenai penerimaan Internet Banking di kalangan intelektual muda Universitas Sabah dengan menggunakan Technology Acceptance Model (TAM). Hasil penelitian menunjukkan bahwa persepsi kemudahan penggunaan dan efisiasi diri mempunyai pengaruh positif dan secara signifikan mempengaruhi minat intelektual muda di Universitas Sabah untuk menggunakan Internet Banking.

Hosein (2010) meneliti mengenai adopsi Internet Banking di China berdasarkan pada pengembangan teori Technology Acceptance Model (TAM). Hasil penelitiannya menemukan bahwa persepsi kemudahan penggunaan menjadi faktor yang paling dominan dalam menentukan seseorang individu untuk mau menggunakan Internet Banking di Shantou, China.

Zahid et all (2010) meneliti mengenai penerimaan nasabah terhadap Online Banking dengan menggunakan Model Technology Acceptance Model (TAM). Penelitian ini menggunakan variabel persepsi kegunaan, persepsi kemudahaan penggunaan dari model TAM ditambah dengan variabel keamanan dan privasi, dan kualitas internet. Hasil penelitiannya menunjukkan bahwa persepsi kegunaan merupakan faktor kunci 


\section{JURNAL NOMINAL / VOLUME III NOMOR 2 / TAHUN 2014}

yang paling mempengaruhi dan memotivasi konsumen dalam mengadopsi Internet Banking di Pakistan.

Dash, Manoranjan et al (2011). Penelitian ini membahas bagaimana pengaruh persepsi kegunaan, kemudahan penggunaan, dan pengaruh sosial terhadap minat penggunaan Internet Banking berlandaskan pada model Technology Acceptance Model (TAM). Hasil penelitian menunjukkan bahwa persepsi kegunaan dan pengaruh sosial mempunyai pengaruh langsung terhadap minat untuk menggunakan Internet Banking. Sementara itu, persepsi kemudahan penggunaan mempunyai pengaruh tidak langsung terhadap minat untuk menggunakan Internet Banking di India.

Cheng et all (2011) meneliti mengenai faktor-faktor yang mempengaruhi penerimaan dan adopsi Internet Banking di Hong Kong dengan menggunakan model teori Technology Acceptance Model (TAM). Penelitian ini menemukan bahwa persepsi akan kegunaan (perceived of ease of use) dan persepsi akan keamanan web (perceived of web security) berpengaruh terhadap persepsi akan kegunaan (perceived of usefulness) dan sikap (attitude) sebagai variabel intervening dan minat untuk menggunakan Internet Banking (intention to use IB) sebagai variabel dependen.

\section{Kerangka Pemikiran}

Kerangka atau model penelitian yang akan digunakan adalah model TAM dengan menambahkan variabel keamanan. Penambahan variabel keamanan ini berdasarkan pada penelitian terdahulu, seperti yang dilakukan oleh Lallmahamood (2007) dan Cheng et all (2011). Mereka berargumen bahwa penambahan variabel keamanan merupakan hal yang penting dilakukan, karena keamanan dianggap sebagai konstruk laten yang dapat mempengaruhi minat seseorang dalam penerimaan sebuah sistem informasi khususnya sistem informasi akuntansi yang terbuka penggunaannya seperti Internet Banking.

Selain berdasarkan penelitian terdahulu, penambahan variabel keamanan ini juga dilakukan dengan memperhatikan fenomena-fenomena kemanan yang terjadi sepanjang penerapan Internet Banking di Indonesia. Pada tahun 2001, terjadi pembobolan terhadap sistem Internet Banking BCA yang dilakukan oleh mantan mahasiswa ITB dengan cara memalsukan nama domain Internet Banking BCA. Kemudian pada tahun 2010 terjadi pembobolan rekening nasabah Bank BCA, BNI, dan Bank Permata yang diduga dilakukan dari Internet Banking dengan menggunakan Trojan Zeus yang disusupi kedalam browser (Republika, 2010). Terakhir pada penghujung tahun 2012 
beredar kabar bahwa telah terjadi kembali penjebolan sistem Internet Banking Bank BCA (klikBCA) yang disebarkan oleh nasabah yang merasa dirugikan melalui pesan singkat di Blackberry Messanger (Detik, 2012).

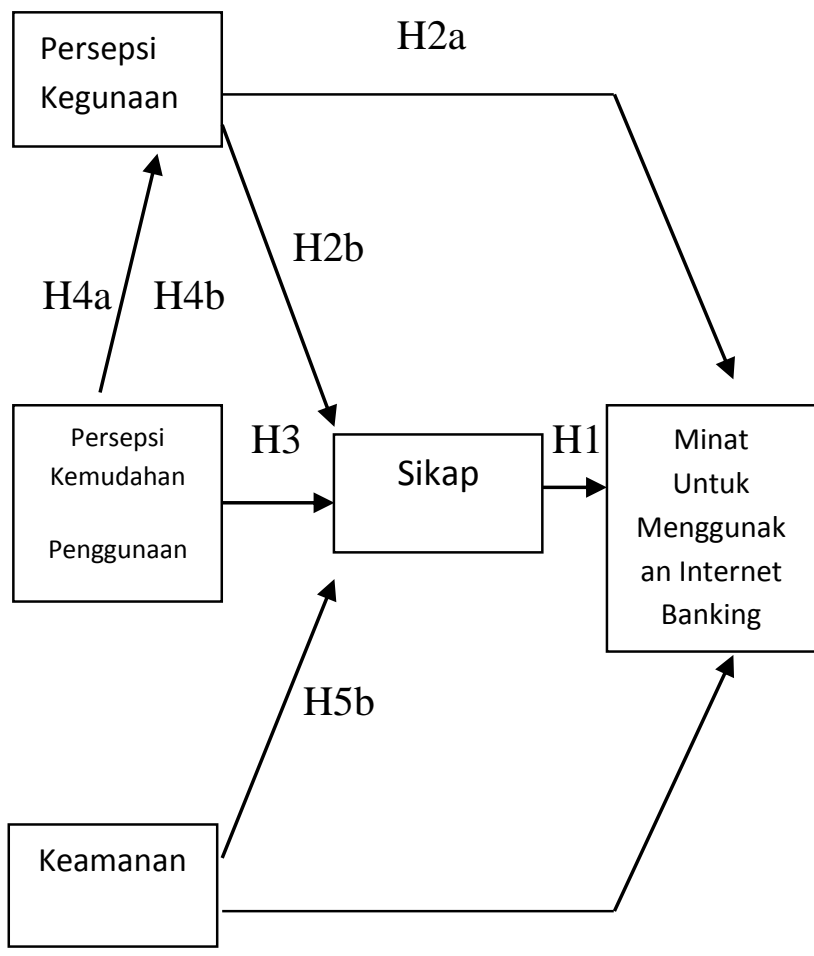

$\mathrm{H} 5 \mathrm{a}$

Gambar 4.1. Kerangka Pemikiran

Sumber : Diolah peneliti berdasarkan sumber

Davis F.D. (1989)

H1 : Sikap berhubungan positif secara langsung dengan minat untuk menggunakan Internet Banking.

H2a : Persepsi kegunaan mempunyai hubungan positif secara langsung dengan minat untuk menggunakan Internet Banking.

$\mathrm{H} 2 \mathrm{~b}$ : Persepsi kegunaan mempunyai hubungan positif secara langsung dengan sikap.

H3 : Persepsi kemudahan penggunaan mempunyai hubungan positif secara langsung dengan sikap.

$\mathrm{H} 4 \mathrm{a}$ : Persepsi kemudahan penggunaan mempunyai hubungan positif secara tidak langsung dengan minat untuk menggunakan Internet Banking melalui persepsi kegunaan.

H4b : Persepsi kemudahan penggunaan mempunyai hubungan positif secara tidak langsung dengan sikap melalui persepsi kegunaan.

H5a : Keamanan mempunyai hubungan positif secara langsung dengan minat untuk menggunakan Internet Banking.

$\mathrm{H} 5 \mathrm{~b}$ : Keamanan mempunyai hubungan positif secara langsung dengan sikap.

\section{METODE PENELITIAN}

\section{Populasi dan Sampel}

Populasi dalam penelitian ini adalah seluruh nasabah Bank Central Asia (BCA) di Kota Palembang. Sementara itu teknik pengambilan sampel yang digunakan adalah purposive sampling yaitu pemilihan elemen untuk menjadi sampel berdasarkan 


\section{JURNAL NOMINAL / VOLUME III NOMOR 2 / TAHUN 2014}

karakteristik tertentu. Karakteristik sampel dalam penelitian ini adalah:

a) Nasabah yang telah terdaftar di Bank Central Asia minimal selama satu tahun terakhir dan aktif melakukan transaksi melalui Bank Central Asia.

b) Nasabah yang mempunyai akses internet. Dari 450 kuisioner yang dibagikan peneliti secara langsung kepada nasabah bank BCA di kota Palembang, hanya 194 kuisioner yang memenuhi karakteristik sampel dan dapat digunakan dalam penelitian ini.

\section{Uji Validitas dan Reliabilitas}

Sebelum melakukan analisis data, dilakukan terlebih dahulu pengujian validitas dan reliabilitas terhadap instrumen penelitian. Hasilnya menunjukkan bahwa rata-rata nilai korelasi antara item pertanyaan dengan total item diatas nilai minimum sebesar 0,1. Oleh karena itu, dapat disimpulkan bahwa semua butir pertanyaan dalam kuisioner penelitian ini valid dan bisa digunakan dalam penelitian ini. Selain itu, bahwa nilai Alpha Cronbach nya sebesar 0,963 diatas nilai minimum sebesar 0,9 . Hal ini menunjukkan bahwa seluruh instrument variabel yang diteliti dinyatakan reliabel dan dapat digunakan untuk tahapan analisis selanjutnya.

\section{Teknik Analisis Data}

Teknik analisis data yang akan digunakan dalam penelitian ini adalah
Structural Equation Modelling (SEM) dengan menggunakan program AMOS 18 (Analysis of Moment Structural). SEM adalah sekumpulan teknik-teknik statistical yang memungkinkan pengujian sebuah hubungan yang relatif rumit secara simultan (Ferdinand, 2002). Hubungan yang rumit itu dapat dibangun antara satu atau beberapa variabel dependen dengan satu atau beberapa variabel dependen. Ada 7 langkah utama dalam melakukan analisis SEM, yaitu:

\section{a. Melakukan pengembangan model teoritis}

Tahap pertama yang harus dilakukan adalah pengembangan model teoritis. Pada tahap ini peneliti melakukan serangkaian eksplorasi ilmiah melalui telaah pustaka guna mendapatkan justifikasi atas model teoritis yang dikembangkan. Model teoritis yang digunakan adalah model TAM yang dimodifikasi dengan menambahkan variabel eksogen keamanan.

\section{b. Pengembangan diagram alur}

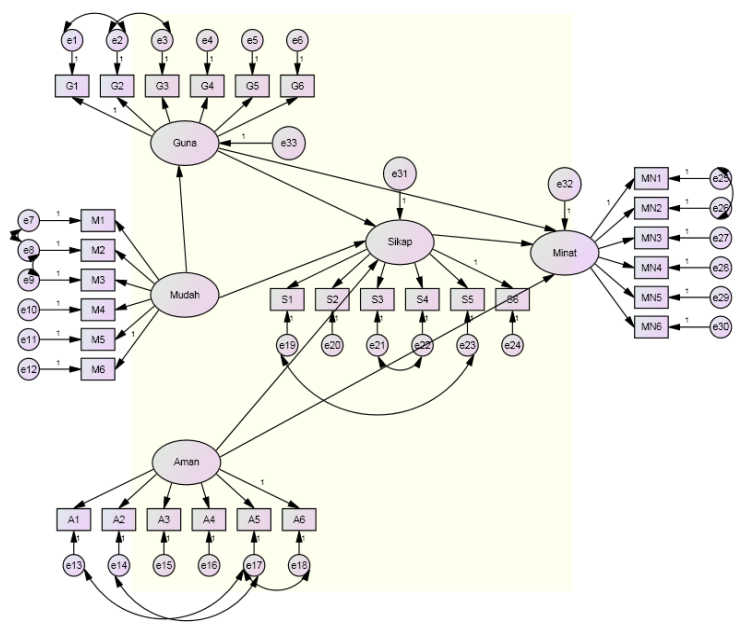


Gambar 2.1. Diagram Alur Penelitian

c. Konversi diagram alur kedalam bentuk persamaan

$$
\begin{aligned}
& \eta_{1}=\gamma_{1} \xi_{1}+\zeta_{1} \\
& \eta_{2}=\beta_{1} \eta_{1}+\gamma_{2} \xi_{1}+\gamma_{3} \xi_{2}+\zeta_{2} \\
& \eta_{3}=\beta_{2} \eta_{1}+\beta_{3} \eta_{2}+\gamma_{4} \xi_{2}+\zeta_{3}
\end{aligned}
$$

\section{d. Menentukan teknik estimasi model}

Tahap keempat adalah estimasi model, teknik estimasi yang akan digunakan adalah Maximum Likelihood Estimation. Pertimbangan penggunaan teknik estimasi model ini adalah karena ukuran sampel dalam penelitian ini tergolong kecil yaitu minimal 175 sampel dan maksimal 350 sampel berdasarkan pada pedoman ukuran sampel SEM (Ferdinand, 2002).

\section{e. Menganalisis}

kemungkinan

\section{munculnya masalah identifikasi}

Tahap kelima adalah mengidentifikasi kemungkinan munculnya masalah yang ditemui pada saat mengoperasikan komputer. Masalah yang diidentifikasi biasanya mengenai ketidakmampuan dari model yang dikembangkan untuk menghasilkan estimasi yang unik. Masalah identifikasi dapat muncul melalui gejala-gejala sebagai berikut:

1) Standard error untuk satu atau beberapa koefisien adalah sangat besar
2) Program tidak mampu menghasilkan matrik informasi yang seharusnya disajikan

3) Muncul angka-angka yang aneh seperti adanya varians error yang negatif

4) Munculnya korelasi yang sangat tinggi antar koefisien estimasi yang didapat

\section{f. Mengevaluasi kriteria goodness of fit}

Tabel 2.1. Hasil Pengujian Goodness of fit Model RMR GFI AGFI PGFI

\begin{tabular}{r|rrrr}
\hline Default model & .113 & .766 & .719 & .639 \\
Saturated & .000 & 1.000 & & \\
model & & & & \\
Independence & .245 & .128 & .067 & .119 \\
model & & & &
\end{tabular}

Model RMSE LO HI PCLOS

\begin{tabular}{r|rrrr} 
& $A$ & 90 & 90 & $E$ \\
\hline Default & .086 & .07 & .09 & .000 \\
model & & 9 & 3 & \\
Independen & .247 & .24 & .25 & .000 \\
ce model & & 1 & 2 &
\end{tabular}

secara keseluruhan dapat disimpulkan bahwa model dalam penelitian ini layak digunakan karena rata-rata nilai GFI, AGFI, dan CFI nya tidak berada dibawah angka 0,70 dan nilai RMSEA nya tergolong marginal fit. Walaupun begitu, 
model dalam penelitian ini juga belum dapat dikatakan sempurna karena nilai GFI, AGFI, dan CFInya belum mencapai angka lebih dari 0,90. Maka berdasarkan pada deskrispi diatas, model ini pada dasarnya memenuhi kriteria marginal fit atau cukup baik untuk digunakan dan dapat dianalisis lebih lanjut.

\section{g. Interpretasi dan modifikasi model}

Langkah terakhir adalah
menginterpretasikan model dan memodifikasikan model bagi modelmodel yang tidak memenuhi syarat pengujian yan dilakukan. Interpretasi berarti mendeskripsikan hasil-hasil pengujian yang telah dilakukan pada tahapan sebelumnya. Modifikasi berarti memperbaiki model jika terdapat ketidak sesuaian.

\section{HASIL PENELITIAN DAN PEMBAHASAN}

Berdasarkan pada pemaparan sebelumnya, maka akan dilakukan pengujian dan pembahasan lebih lanjut terhadap hipotesis yang ada. Hal ini bertujuan untuk memperdalam bahasan terhadap hasil pengujian hipotesis.
Pengaruh Sikap terhadap Minat untuk Menggunakan Internet Banking

Berdasarkan pada hasil analisis model struktural, besarnya pengaruh langsung sikap dan minat untuk menggunakan Internet Banking adalah sebesar 0,485 dengan nilai Critical Ratio (CR) sebesar 4,343 dan Probabilitas (P) sebesar 0,000. Karena nilai CR > 1,96 dan nilai $\mathrm{P}<0,05$ maka dapat disimpulkan bahwa terdapat pengaruh langsung yang signifikan antara sikap terhadap minat untuk menggunakan Internet Banking.

Nilai koefisien pengaruh langsung sikap dan minat untuk menggunakan Internet Banking sebesar 0,555 menunjukkan tanda yang positif. Hal ini mengindikasikan bahwa pengaruh sikap terhadap minat untuk menggunakan Internet Banking adalah positif. Artinya, jika nilai variabel laten sikap naik 0,555 maka nilai variabel minat untuk menggunakan Internet Banking juga akan naik sebesar 0,555. Jadi dapat disimpulkan bahwa sikap nasabah Bank BCA di Kota Palembang berpengaruh positif dengan minat nasabah untuk menggunakan Internet Banking BCA. Dengan demikian, maka "H1: Sikap berhubungan positif secara langsung dengan minat untuk menggunakan Internet Banking" dapat diterima dalam penelitian ini.

Dalam penelitian ini, bentuk kepercayaan yang dievaluasi oleh sikap ditunjukkan oleh persepsi kegunaan, persepsi 


\section{JURNAL NOMINAL / VOLUME III NOMOR 2 / TAHUN 2014}

kemudahan penggunaan, dan persepsi keamanan dari nasabah BCA. Oleh karena itu, semakin positif sikap dari nasabah terdsebut, maka semakin tinggi pula minatnya untuk mau beradaptasi dan menggunakan Sistem Informasi Akuntansi Perbankan berupa Internet Banking.

\section{Pengaruh Persepsi Kegunaan terhadap Minat untuk Menggunakan Internet Banking}

Berdasarkan pada hasil analisis
model struktural, besarnya pengaruh langsung persepsi kegunaan terhadap minat untuk menggunakan Internet Banking adalah sebesar 0,124 dengan nilai Critical Ratio (CR) sebesar 1.292, dan Probabilitas (P) sebesar 0,196. Karena nilai CR $<1.96$, dan nilai $\mathrm{P}>0.05$, sehingga dapat dijelaskan bahwa tidak terdapat pengaruh langsung yang signifikan antara persepsi kegunaan terhadap minat untuk menggunakan Internet Banking. Dengan demikian, "H2a: Persepsi kegunaan mempunyai hubungan positif secara langsung dengan minat untuk menggunakan Internet Banking" ditolak dalam penelitian ini.

Walaupun tidak terdapat pengaruh langsung, besarnya pengaruh persepsi kegunaan terhadap minat untuk menggunakan Internet Banking dapat dijelaskan juga melalui hubungan secara tidak langsung yang diperantarai oleh variabel sikap. Dari hasil pengujian pengaruh tidak langsung antara persepsi kegunaan dengan minat untuk menggunakan Internet Banking, maka didapatkan nilai 0,276. Artinya, jika nilai variabel persepsi kegunaan naik sebesar 0,276 maka nilai variabel minat untuk menggunakan Internet Banking juga akan naik sebesar 0,276. Jadi apabila nilai persepsi kegunaan tinggi maka minat untuk menggunakan Internet Banking juga akan tinggi apabila didukung oleh nilai sikap yang tinggi, dan begitu juga sebaliknya.

Hal ini tidak sejalan dengan dasar teori Technology Acceptance Model (TAM) yang dikemukakan oleh Davis pada tahun 1989, dimana Davis menyatakan bahwa persepsi kegunaan mempunyai pengaruh secara langsung dan signifikan terhadap minat seorang individu untuk menggunakan sistem informasi berbasiskan pada teknologi. Selain itu, hasil penelitian ini juga bertentangan dengan hasil penelitian Alsajjan dan Dennis (2006), Lallmahamood (2007), Amin (2007), Lee (2008), Zahid et all (2010), Dash, Manoranjan et al (2011), Cheng et all (2011), dan Safeena et all (2011) .

Berdasarkan pada analisis peneliti, faktor utama yang menyebabkan terjadinya perbedaan hasil penelitian ini dengan dasar teori TAM dan penelitian terdahulu lebih kepada masalah demografis. Faktor 


\section{JURNAL NOMINAL / VOLUME III NOMOR 2 / TAHUN 2014}

demografis seperti perbedaan tempat dan waktu dilakukannya penelitian menjadi penyebab utama terjadinya perbedaan hasil pengujian hipotesis ini. Perbedaan tempat dan waktu dilakukannya penelitian tentunya akan mengakibatkan perbedaan kebudayaan dan pola pikir populasi yang dijadikan objek penelitian. Seperti halnya penelitian yang dilakukan Cheng et all (2011) di China tentunya akan mempunyai kemungkinan terdapat perbedaan dengan penelitian ini yang dilakukan di Indonesia.

\section{Pengaruh Persepsi Kegunaan terhadap Sikap}

Berdasarkan hasil analisis model struktual, besarnya pengaruh langsung persepsi kegunaan terhadap sikap adalah 0,570 dengan nilai Critical Ratio (CR) sebesar 6,157 dan Probabilitas (P) sebesar 0,000. Karena nilai $\mathrm{CR}>1,96$, dan nilai $\mathrm{P}<$ 0,05 maka dapat dijelaskan bahwa terdapat pengaruh langsung yang signifikan variabel persepsi kegunaan terhadap sikap.

Nilai koefisien pengaruh langsung persepsi kegunaan terhadap sikap sebesar 0,527 menunjukkan bahwa terdapat pengaruh positif variabel persepsi kegunaan terhadap sikap. . Artinya, jika nilai variabel persepsi kegunaan naik sebesar 0,527 maka nilai variabel sikap juga akan naik sebesar 0,527. Jadi, semakin baik persepsi kegunaan seseorang, maka semakin baik juga sikapnya dan sebaliknya. Dengan demikian, "H2b:

\section{Persepsi kegunaan mempunyai hubungan} positif secara langsung dengan sikap" diterima dalam penelitian ini.

Hal ini sejalan dengan dasar teori Technology Acceptance Model (TAM) yang dikemukakan oleh Davis pada tahun 1989. Davis menyatakan bahwa persepsi kegunaan mempunyai pengaruh positif secara langsung dengan sikap. Dimana, persepsi kegunaan merupakan salah satu variabel yang menjadi bagian dari evaluasi kepercayaan untuk pembentukkan sebuah sikap, hal ini juga diperkuat dengan penelitian terdahulu (Karjaluoto, 2002; Lallmahamood, 2007; Cheng et al, 2011).

\section{Pengaruh Persepsi Kemudahan Penggunaan terhadap Sikap}

Berdasarkan hasil analisis model struktual, besarnya pengaruh langsung persepsi kemudahan penggunaan terhadap sikap adalah 0,166 dengan nilai Critical Ratio (CR) sebesar 2,216 dan Probabilitas (P) sebesar 0,027. Karena nilai CR > 1.96, dan nilai $\mathrm{P}<0.05$, sehingga dapat dijelaskan bahwa terdapat pengaruh langsung yang signifikan dari variabel persepsi kemudahan penggunaan terhadap variabel sikap.

Nilai koefisien pengaruh langsung persepsi kemudahan penggunaan terhadap sikap sebesar 0,107 menunjukkan bahwa terdapat pengaruh positif variabel kemudahan penggunaan terhadap sikap. Artinya, jika nilai variabel persepsi 
kemudahan pengunaan naik sebesar 0,107 maka nilai variabel sikap juga akan naik sebesar 0,107. Jadi, semakin baik persepsi kegunaan nasabah, maka semakin tinggi pula sikap dan sebaliknya.

Jadi dapat disimpulkan bahwa persepsi kemudahan penggunaan nasabah Bank BCA di Kota Palembang mempunyai pengaruh positif secara langsung dengan sikap nasabah untuk berperilaku. Dengan demikian, "H3: Persepsi kemudahan penggunaan mempunyai hubungan positif secara langsung dengan sikap" diterima dalam penelitian ini.

Hal ini juga sejalan dengan dasar teori Technology Acceptance Model (TAM) yang dikemukakan oleh Davis pada tahun 1989 dan penelitain terdahulu (Alsajjan dan Dennis, 2006; Lallmahamood, 2007; Cheng et al, 2011). Davis menyatakan bahwa persepsi kemudahan penggunaan berpengaruh positif secara langsung dengan sikap pengguna akhir. Dimana persepsi kemudahan penggunaan juga merupakan salah satu variabel yang menjadi bagian evaluasi kepercayaan untuk pembentukkan sebuah sikap. Dalam penelitian ini, persepsi kemudahan penggunaan nasabah BCA juga menjadi bagian dasar pertimbangan dari penentuan sebuah sikap terhadap minat untuk menggunakan Sistem Informasi Akuntansi Perbankan berupa Internet Banking BCA.
Pengaruh Persepsi Kemudahan

Penggunaan terhadap Minat untuk Menggunakan Internet Banking secara tidak langsung melalui Persepsi Kegunaan

Berdasarkan hasil analisis model struktural, pengaruh persepsi kemudahan penggunaan terhadap minat untuk menggunakan Internet Banking dapat dijelaskan melalui hubungan secara tidak langsung yang diperantarai oleh variabel persepsi kegunaan dengan nilai sebesar 0,346. Hal ini menunjukkan bahwa hubungan secara tidak langsung antara persepsi kemudahan penggunaan terhadap minat untuk menggunakan Internet Banking bernilai positif. Artinya, jika nilai variabel persepsi kemudahan penggunaan naik sebesar 0,346 maka nilai variabel persepsi kegunaan dan sikap juga akan naik sebesar 0,346. Jadi apabila nilai persepsi kemudahan penggunaan tinggi, maka minat untuk menggunakan Internet Banking juga akan tinggi dengan syarat didukung oleh nilai persepsi kegunaan yang tinggi juga dan sebaliknya.

Jadi dapat disimpulkan bahwa persepsi kemudahan penggunaan nasabah Bank BCA di Kota Palembang berpengaruh positif secara tidak langsung terhadap minat untuk menggunakan Internet Banking BCA melalui persepsi kegunaan. Dengan demikian, "H4a: Persepsi kemudahan penggunaan mempunyai hubungan positif 


\section{secara tidak langsung dengan minat} untuk menggunakan Internet Banking melalui persepsi kegunaan" diterima dalam penelitian ini.

Hal ini sejalan dengan dasar teori Technology Acceptance Model (TAM) yang dikemukakan oleh Davis pada tahun 1989 dan beberapa penelitian terdahulu (Alsajjan dan Dennis, 2006; Amin, 2007; Lallmahamood, 2007; Cheng et al, 2011). Davis menyatakan bahwa persepsi kemudahan penggunaan berpengaruh terhadap minat untuk menggunakan Internet Banking secara tidak langsung melalui persepsi kegunaan. Davis juga berargumentasi bahwa persepsi kemudahan penggunaan merupakan bagian evaluasi dari persepsi kegunaan yang kemudian akan mempengaruhi minat pengguna untuk menggunakan sebuah sistem informasi yang berbasiskan pada teknologi.

\section{Pengaruh Persepsi Kemudahan Penggunaan terhadap Sikap Melalui Persepsi Kegunaan}

Berdasarkan hasil analisis model struktural, pengaruh persepsi kemudahan penggunaan terhadap minat untuk menggunakan Internet Banking dapat dijelaskan melalui hubungan secara tidak langsung yang diperantarai oleh variabel persepsi kegunaan dengan nilai sebesar 0.378. Hal ini menunjukkan adanya hubungan positif secara tidak langsung antara persepsi kemudahan penggunaan terhadap sikap melalui persepsi kegunaan. Artinya, jika nilai variabel persepsi kemudahan penggunaan naik sebesar 0,378 maka nilai variabel persepsi kegunaan dan sikap juga akan naik sebesar 0,378. Jadi apabila persepsi kemudahan penggunaan tinggi, maka sikap juga tinggi apabila didukung oleh nilai persepsi kegunaan yang juga tinggi dan sebaliknya.

Jadi dapat disimpulkan bahwa persepsi kemudahan penggunaan nasabah Bank BCA di Kota Palembang berpengaruh positif secara tidak langsung terhadap sikap nasabah untuk berperilaku melalui persepsi kegunaan. Dengan demikian, “H4b: Persepsi kemudahan penggunaan mempunyai hubungan positif secara tidak langsung dengan sikap melalui persepsi kegunaan" diterima dalam penelitian ini.

Hal ini sejalan dengan dasar teori Technology Acceptance Model (TAM) yang dikemukakan oleh Davis pada tahun 1989 dan penelitian terdahulu (Alsajjan dan Dennis, 2006; Amin, 2007; Lallmahamood, 2007; Cheng et al, 2011). Davis menyatakan bahwa persepsi kemudahan penggunaan berpengaruh positif secara tidak langsung terhadap sikap melalui persepsi kegunaan. Hampir sama dengan pernyataan sebelumnya, Davis juga berargumentasi bahwa perpsepsi kemudahan penggunaan merupakan bagian evaluasi dari persepsi 


\section{JURNAL NOMINAL / VOLUME III NOMOR 2 / TAHUN 2014}

kegunaan yang pada akhirnya akan mempengaruhi sikap seorang pengguna untuk berperilaku.

Pengaruh Persepsi Keamanan terhadap Minat untuk Menggunakan Internet Banking

Berdasarkan hasil analisis model struktual, pengaruh persepsi keamanan terhadap minat untuk menggunakan Internet Banking mempunyai nilai sebesar 0,263 dengan nilai Critical Ratio (CR) sebesar 3,458 dan Probabilitas (P) sebesar 0.000. Karena nilai $\mathrm{CR}>1,96$ dan nilai $\mathrm{P}<0,05$, sehingga dapat dijelaskan bahwa terdapat pengaruh langsung yang signifikan antara variabel keamanan dengan minat untuk menggunakan Internet Banking.

Nilai koefisien pengaruh langsung keamanan terhadap minat untuk menggunakan Internet Banking sebesar 0.227 menunjukkan bahwa pengaruh persepsi keamanan terhadap minat untuk menggunakan Internet Banking adalah positif. Artinya, jika nilai variabel persepsi keamanan naik sebesar 0,227 maka nilai variabel minat untuk menggunakan Internet Banking juga akan naik sebesar 0,227. Jadi, semakin baik persepsi keamanan seseorang, maka semakin tinggi minat untuk menggunakan Internet Banking dan begitu juga sebaliknya. Dengan demikian, "H5a: Keamanan mempunyai hubungan positif secara langsung dengan minat untuk menggunakan Internet Banking" diterima dalam penelitian ini.

Penambahan variabel keamanan dalam penelitian ini sejalan dengan penelitian yang dilakukan oleh Cheng et al (2003) dan Lallmahamood (2007). Alasan penambahan variabel keamanan ini dilakukan karena mereka merasa bahwa faktor keamanan merupakan hal yang perlu diperhatikan dalam penggunaan Sistem Informasi Akuntansi Perbankan yang berbasis teknologi seperti Internet Banking. Cheng et al lebih menyoroti keyakinan diri seorang nasabah terhadap keamanan dan kerahasiaan akan informasi pribadi ketika melaksanakan transaksi perbankan melalui Internet Banking.

\section{Pengaruh Persepsi Keamanan terhadap} Sikap

Berdasarkan hasil analisis model struktual, pengaruh persepsi keamanan terhadap sikap mempunyai nilai sebesar 0,357 dengan nilai Critical Ratio (CR) sebesar 5,761 dan Probabilitas (P) sebesar 0,000. Karena nilai CR > 1.96, dan nilai $\mathrm{P}<$ 0.05, sehingga dapat dijelaskan bahwa terdapat pengaruh langsung yang signifikan antara variabel persepsi keamanan dengan sikap. Nilai koefisien pengaruh langsung keamanan terhadap sikap sebesar 0,269 menunjukkan pengaruh positif antara variabel keamanan dengan sikap. Artinya, jika nilai variabel persepsi keamanan naik 


\section{JURNAL NOMINAL / VOLUME III NOMOR 2 / TAHUN 2014}

sebesar 0,269 maka nilai variabel sikap juga akan naik sebesar 0,269. Hal ini menunjukkan semakin baik persepsi keamanan nasabah, maka semakin tinggi pula sikap untuk berperilakunya dan sebaliknya. Jadi dapat disimpulkan bahwa persepsi keamanan nasabah Bank BCA di Kota Palembang berpengaruh positif secara langsung terhadap sikap nasabah untuk berperilaku. Dengan demikian, "H5b: Keamanan mempunyai hubungan positif secara langsung dengan sikap" diterima dalam penelitian ini.

Hasil penelitian ini sejalan dengan penelitian Cheng et al (2003), dimana Cheng juga menemukan terdapat pengaruh Persepsi keamanan nasabah bank di Hongkong terhadap penggunaan Internet Banking. Jadi dapat disimpulkan bahwa terdapat pengaruh positif secara langsung dari persepsi keamanan nasabah Bank BCA terhadap sikap untuk berperilaku yang merupakan evaluasi dari berbagai struktur yang menyusun kepercayaannya.

Berdasarkan pada keseluruhan pengujian hipotesis yang telah dilakukan, maka dapat disimpulkan bahwa hanya satu hipotesis dalam penelitian ini yang ditolak yaitu "Persepsi kegunaan mempunyai hubungan positif secara langsung dengan minat untuk menggunakan Internet Banking". Sementara itu, ketujuh hipotesis lainnya terbukti dan dapat diterima dalam penelitian ini.

\section{SIMPULAN DAN SARAN}

\section{Kesimpulan}

Berdasarkan pada pembahasan masalah yang telah dijabarkan sebelumnya, maka peneliti dapat menarik kesimpulan bahwa minat nasabah Bank Central Asia khususnya yang berada di kota Palembang untuk menggunakan Sistem Informasi Akuntansi Perbankan berupa Internet Banking dipengaruhi baik secara langsung maupun tidak langsung berdasarkan pada persepsi kegunaan, kemudahaan penggunaan, keamanan, dan sikap. Hal ini sesuai dengan dasar teori Technology Acceptance Model (TAM) yang dikemukakan oleh Davis pada tahun 1989.

Selain itu juga ditemukan fenomena bahwa persepsi kegunaan nasabah BCA di Kota Palembang ternyata tidak mempunyai pengaruh positif secara langsung dengan minat untuk menggunakan Internet Banking, melainkan hanya mempunyai pengaruh positif secara tidak langsung melalui variabel laten sikap. Hal ini membuat persepsi kegunaan hanya berfungsi sebagai perwujudan kepercayaan yang dievaluasi dalam penentuan sikap nasabah.

\section{Saran dan Keterbatasan}

Berdasarkan pada hasil penelitian ini, peneliti mencoba memberikan saran bagi penelitian selanjutnya:

a. Peneliti menemukan bahwa tidak terdapat hubungan positif secara langsung antara 
persepsi kegunaan dengan minat untuk menggunakan Internet Banking BCA, namun persepsi kegunaan berpengaruh positif secara tidak langsung terhadap minat melalui sikap. Fenomena ini dapat disebabkan karena adanya perbedaan demografis, sehingga penelitian berikutnya disarankan untuk lebih memperhatikan dan memperdalam hal ini.

b. Peneliti menyadari keterbatasan sampel pada penelitian ini, sehingga kedepannya peneliti menyarankan penelitian selanjut dilakukan dengan jumlah sampel yang lebih besar agar hasilnya lebih maksimal.

\section{DAFTAR PUSTAKA}

Alsajjan, Bander A dan Dennis, Charles (2006), "The Impact of Trust on Acceptance of Online Banking" European Association of Education and Research, Distribution 27-30 Brunei University - West London, United Kingdom.

Amin, Hanudin (2007), "Internet Banking Adoption Among Young Intellectuals" Journal of Internet Banking, vol. 12, no.3, pages 32-51.

Bussakorn (2005), “Internet Banking Adoption Strategies for a Developing Country: The Case of Thailand" Internet Research, Vol. 15, No. 3, pages 71-84.
Cheng, T.C., Edwin, David, Lam danYeung, Andy (2003) "Adoption of Internet Banking: An Empirical Study in Hong Kong” Hung Hoom, Kowloon University.

Davis, F.D. (1989) "Measurement Scales for Perceived Usefulness and Perceived Ease of Use" Journal of Information System Research.

Davis, F.D. (1989) "User Acceptance of Computer Technology: A Comparison of Two Theoriticals Model. Journal of Information System Research" Vol. 35, No. 8, pages 117-141.

Dash, Manoranjan et al. (2011) "Using the TAM Model to Explain How Attitudes Determine Adoption of Internet Banking” European Journal of Economics, Finance and Administrative Sciences ISSN 14502275 Issue 36.

DeLone, WH., dan McLean, ER. (1992) "Information Systems Success: The Quest for the Dependent Variable” Information System Research, 3(1), pages 60-95.

DeLone, WH., dan McLean, ER. (2003) "The DeLone and McLean model of information systems success: a tenyear update" Journal of Management Information Systems 19(4), pages 930.

Esia, Uwem and Eddet (2012) "Factors that Affect Adoption of $E$ Banking 


\section{JURNAL NOMINAL / VOLUME III NOMOR 2 / TAHUN 2014}

Products and Services in Nigeria" European Journal of Economics,

Finance and Administrative Sciences.

Ferdinand, Agusty (2002). Structual

Equation Model. Semarang: BP Undip.

Gerrad, Phillip., Devlin, James., and Barton. (2007) "Why Consumer Are Not Using Internet Banking: A Qualitative Study" European Journal of Economics, Finance and Administrative Sciences ISSN 08876045 Issue 14.

Ghozali, Imam (2011). Aplikasi Analisis Multivariate Dengan Program IBM SPSS 19 Semarang. Badan Penerbit Universitas Diponegoro. ISBN: 979.704.015.1.

Ghozali, Imam (2011). Model Persamaan Strutural Konsep Dan Aplikasi Dengan Program AMOS 21.0. Semarang. Badan Penerbit Universitas Diponegoro. ISBN: 979.704.233.2.

Hall, James. (2009). Sistem Informasi Akuntansi". Salemba Empat. Jakarta.

Hosein, Nasim Z (2010) "Internet Banking: Understanding consumer adoption rates among community banks" Shantou University, China.

Jogiyanto. (2007). Sistem Informasi Keperilakuan. Andi. Jogyakarta.

Kamariah Nik., Ernovianti, Umar, Rashaan dan Mai (2012) “The Usage of Internet Banking Service among Higher Learning Students in Malaysia"
American Journal of Economics, Special Issue: 105-108.

Karjaluoto (2002) "Electronic Banking In Finland" Jyvaskyla Studies in Economics 18.

Kusuma, Hadri dan Dwi (2007) "Determinan Pengadopsian Layanan Internet Banking: Perspektif Konsumen Perbankan Daerah Istimewa Yogyakarta” Jurnal Akuntansi dan Auditing Indonesia.

Lallmahamood, Muniruddeen (2007) "An Examination of Individual's Perceived Security and Privacy of the Internet in Malaysia and the Influence of This on Their Intention to Use E-Commerce: Using An Extension of the Technology Acceptance Model" Journal of Internet Banking, Vol. 12, no.3, pages 91-112.

Lee, Ming-Chi (2008) "Factors influencing the adoption of Internet Banking: An integration of TAM and TPB with perceived risk and perceived benefit" Electronic Commerce Research and Applications 8, pages 130-141.

Lydia (2005) “Analisis Niat Perilaku Menggunakan Internet Banking di Kalangan Pengguna Internet Surabaya" Jurnal Widya Akuntansi. Vol. 5, No. 1, pages 101-123.

Mahardika dan Rachmat, Basuki (2011) "Factors Determining Acceptance Level of Internet Banking Implementation" Journal of 


\section{JURNAL NOMINAL / VOLUME III NOMOR 2 / TAHUN 2014}

Economics, Business and Accountancy

Ventura Volume 14, No. 2, pages 161 -174 .

Malhotra, Pooja (2007) "Determinants of Internet Banking adoption by banks in India" Internet Research. Vol. 17 No. 3, pages 323-339.

Nasri, Wadie (2011) "Factors Influencing the Adoption of Internet Banking in Tunisia" International Journal of Accounting. Vol. 6, No. 8. Pages 1228.

Oviliani. (2000) "Penggunaan Teknologi Internet dalam Bisnis" Jurnal Akuntansi \& Keuangan. Vol. 2, No. 1: $36-52$.

Qatawneh, Adel M. (2012) "The Effect of Electronic Commerce on the Accounting Information System of Jordanian Banks" Department of Accounting, Al-Zaytoonah University of Jordan, Amman, Jordan.

Riyadh Al Nahian., Akter Md. Shahriar., dan Nayeema (2009) "The Adoption of Ebanking in Developing Countries: A Theoretical Model for SMEs" International Review of Business Research Papers. Vol. 5 No. 6, Pp.212-230.

Safeena, Rahmath., Date, Hema., and Kammani Abdullah (2011) "Internet Banking Adoption in an Emerging Economy: Indian Consumer's Perspective" International Arab
Journal of Information System. Vol. 2, No. 1.

Santoso, Singgih. (2011). Structual Equation Model (SEM) Konsep dan Aplikasi dengan AMOS 18. Elex Media Komputindo: Jakarta.

Satrio (2011) “Analisis Faktor-Faktor yang Mempengaruhi Consumer Acceptance Terhadap SMS Banking Mandiri” Jurnal Akuntansi Keuangan Indonesia. Savitri, Ni Made dan Nyoman, Ni (2012) "EService Quality Terhadap Kepuasan dan Loyalitas Pelanggan dalam Penggunaan Internet Banking" Jurnal Keuangan dan Perbankan, Vol.16, No.2, halaman. 293-306.

Shim, Eastlick, Lotz dan Warrington, $\mathrm{P}$ (2001) "An online prepurchase intentions model: the role of intention to search. Journal of Retailing" 77, 397-416.

Sok Foon, Yeoh (2011) "Internet Banking Adoption in Kuala Lumpur: An Application of UTAUT Model" International Journal of Economic and Business. Vol. 6, No. 4.

Sri dan Yuliani (2011) "Faktor-Faktor yang Mempengaruhi Minat Nasabah Menggunakan Internet Banking dengan Menggunakan Kerangka Technology Acceptance Model (TAM)" Diambil dari http://puslit.petra.ac.id/journals/accoun ting pada April 2011. 
Sugiarto, Agung (2012) “Adopsi Internet www.infobanknews.com pada Mei 2013

Banking Bagi Keunggulan Performa Perbankan: Sebuah Studi pada Sektor Perbankan di Indonesia” Jurnal Dinamika Akuntansi Vol. 4, No. 1, pages 13-19.

Taylor and Todd. (1995) "User Acceptance of E-Commerce Technology: A MetaAnalytic Comparison Of Competing Models" Florida Atlantic University.

Tong, Canon (2012) "The Influences of Service Personalization, Customer Satisfaction and Switching Costs on ELoyalty" International Journal of Economic and Finance. Vol. 4, No. 3.

Venkatesh, V. and Morris, M.G., (2003) "Why don't men ever stop to ask for directions? gender, social influence, and their role in technology acceptance and usage behavior" MIS Quarterly, 24, pages 115-139.

Yusnaini (2010) "Pengaruh Kualitas Pelayanan Internet Banking Terhadap Kepuasan dan Loyalitas Konsumen pada Bank Swasta" Jurnal Dinamika Akuntansi. Vol. 2, No. 1, pages 1-9.

Zahid, Nauman, Mujtaba, Asif, and Riaz, Adnan (2010) "Consumer Acceptance of Online Banking” European Journal of Economics, Finance and Administrative Sciences ISSN 14502275 Issue 27.

www.bca.co.id diakses pada Mei 2013

www.internetworldstats.com pada Mei 2013 